\title{
A new Keynesian model with endogenous technology trend
}

Citation for published version (APA):

Kuehn, S. (2010). A new Keynesian model with endogenous technology trend. METEOR, Maastricht University School of Business and Economics. METEOR Research Memorandum No. 040 https://doi.org/10.26481/umamet.2010040

Document status and date:

Published: 01/01/2010

DOI:

10.26481/umamet.2010040

Document Version:

Publisher's PDF, also known as Version of record

\section{Please check the document version of this publication:}

- A submitted manuscript is the version of the article upon submission and before peer-review. There can be important differences between the submitted version and the official published version of record.

People interested in the research are advised to contact the author for the final version of the publication, or visit the DOI to the publisher's website.

- The final author version and the galley proof are versions of the publication after peer review.

- The final published version features the final layout of the paper including the volume, issue and page numbers.

Link to publication

\footnotetext{
General rights rights.

- You may freely distribute the URL identifying the publication in the public portal. please follow below link for the End User Agreement:

www.umlib.nl/taverne-license

Take down policy

If you believe that this document breaches copyright please contact us at:

repository@maastrichtuniversity.nl

providing details and we will investigate your claim.
}

Copyright and moral rights for the publications made accessible in the public portal are retained by the authors and/or other copyright owners and it is a condition of accessing publications that users recognise and abide by the legal requirements associated with these

- Users may download and print one copy of any publication from the public portal for the purpose of private study or research.

- You may not further distribute the material or use it for any profit-making activity or commercial gain

If the publication is distributed under the terms of Article $25 \mathrm{fa}$ of the Dutch Copyright Act, indicated by the "Taverne" license above, 


\section{Maastricht University}

Stefan Kühn

A New Keynesian Model with Endogenous Technology Trend

$\mathrm{RM} / 10 / 040$

\section{METEOR}

Maastricht University School of Business and Economics

Maastricht Research School of Economics

of Technology and Organization

P.O. Box 616

NL - 6200 MD Maastricht

The Netherlands 


\title{
A New Keynesian Model with Endogenous Technology Trend
}

\author{
Stefan Kühn*
}

August 6, 2010

WORKING PAPER

\begin{abstract}
This paper extends a New Keynesian model with features of endogenous growth. This allows temporary shocks to have persistent effects, which in turn feeds back to short run demand and thus changes both the short and medium run response of the economy. The first major finding is that the model explains consumption crowdingin. Furthermore, monetary policy affects long run output, and the paradox of thrift can occur. Finally, the analysis is extended with a zero bound on monetary policy. Besides causing a long run loss in output, the loss of power of monetary policy causes a more severe short run deflationary spiral in the presence of endogenous growth. Additionally, fiscal policy becomes much more powerful.
\end{abstract}

JEL code: E20, E62, O40

Keywords: New Keynesian Macroeconomics, Endogenous Growth, Crowding in, Spending Multipliers, Zero Lower Bound

\section{Introduction}

Traditional New Keynesian models deal with temporary fluctuations of economic variables around a steady state. The effects of monetary and fiscal policy on these fluctuations are well known. Once these fluctuations fade away, the economy returns to its predetermined steady state. Thus, both shocks and policy don't have persistent effects.

Section 2.1 makes clear that this is inappropriate. Temporary fluctuations in output have persistent effects. This implies that policy choices do not only have short run but also long run consequences. To our knowledge, the only existing paper discussing this aspect is Rannenberg (2009) in the context of the impact of monetary policy on the NAIRU.

${ }^{*}$ Department of Economics, Maastricht University, P.O. Box 616, 6200MD Maastricht, The Netherlands, E-Mail: s.kuehn@maastrichtuniversity.nl 
This paper presents a New Keynesian endogenous growth model, where the source as well as the degree of endogenous growth is adaptable. I refrain from any further rigidities besides price stickiness in order to show as clearly as possible the additional value of endogenous growth in the New Keynesian model. However, this model can be extended by any rigidities the standard New Keynesian model knows.

Endogenous growth adds an additional determinant to consumption and investment demand. During favourable current economic conditions learning-by-doing is enhanced, thereby increasing future output and current demand. Therefore, similar sized shocks have a larger short run consequence compared to the exogenous growth model. Moreover, shocks also have persistent effects due to the presence of the endogenous growth channel. I will show these short and long run consequences for a variety of shocks. I can furthermore confirm the result by Rannenberg (2009) that a larger weight of monetary policy on the output gap leads to a smaller long-run output loss in face of an adverse productivity shock.

The New Keynesian endogenous growth model allows a novel explanation for the consumption crowding-in puzzle. Blanchard and Perotti (2002) and many other authors have found that private consumption rises in face of a government spending shock. ${ }^{1}$ In response to that, a large number of papers have appeared presenting different mechanisms that allow a New Keynesian model to show crowding-in (i.e. Linnemann and Schabert, 2003; Galí et al., 2007). Kühn et al. (2010) discusses these in a systematic way and proposes, using a graphical framework, the mechanism modelled explicitly in this paper to obtain crowding-in.. Increased economic activity due to government spending increases medium run output and consumption, which, due to consumption smoothing, increases short run consumption demand and thereby causes consumption crowding-in. This channel is new and independent of all others presented in existing literature.

I furthermore extend the model by a zero bound constraint of the nominal interest rate. While the general consequences are the same as in an exogenous growth New Keynesian model (reviewed in Section 2.2), endogenous growth amplifies these effects due to the depressing effect of adverse current economic conditions on demand. Furthermore, the inability of monetary policy to react to deflationary conditions also leads to a permanent output loss. However, the fiscal multiplier, which is large under a zero bound to begin with, also increases with endogenous growth. This is in line with the finding of Christiano et al. (2009), who find that fiscal multipliers are larger in situations where the output loss from the zero bound is larger as well. Finally, I can also show that the paradox of thrift, where a higher savings desire will actually lead to lower savings and investment, can

\footnotetext{
${ }^{1}$ I am aware of the critique by Ramey (2009). A full survey on that discussion is beyond the scope of this paper.
} 
actually be present in the New Keynesian endogenous growth model.

This paper first surveys the literature dealing with permanent effects of temporary output fluctuations as well as with government spending in the presence of a zero bound. Next, it presents the New Keynesian endogenous growth model. Section 4 presents our approach to simulate the model. Afterwards, Section 5 presents the results. Finally, Section 6 concludes.

\section{Literature Review}

This section first discusses literature showing and utilising the fact that output possesses a unit root and is path dependent. This directly leads to endogenous growth models, which are very briefly surveyed. Afterwards, this section surveys literature discussing the effects of government spending in an economy constrained by a zero bound on the nominal interest rate.

\subsection{Path Dependence of Output}

Campbell and Mankiw (1987) pose the interesting question why macroeconomics essentially seems to be concerned with fluctuations of output around a trend, which in itself is more or less fixed (see line (a) in Figure 1). The New Keynesian literature additionally uses monetary policy to refine these movements around that trend. However, policy does not have long-run consequences. In contrast to that, growth economists are concerned with the transition to that trend, or, in endogenous growth theory, with the determination of the slope of that trend (see line (b) in Figure 1). This strict separation is unappropriate. This section argues that a macroeconomic model should not only deal with short run fluctuations, but also with their impact on the medium run potential output (represented by line (c) in Figure 1).

Steindl and Tichy (2009) provide a comprehensive survey of literature where cycles and growth are regarded jointly. Apart from the classical literature (Schumpeter, 1939), they state that Nelson and Plosser (1982) started a discussion on the nature of dynamics of economic time series. This led Campbell and Mankiw (1987) to argue that output has a unit root and that a $1 \%$ short run change in output will lead lead to a more than $1 \%$ change in long run output. While their estimates of the size of the effects have to be taken with care, as also shown by Diebold and Rudebusch (1989), the general idea was also confirmed recently by Murray and Nelson (2002).

The apparent non-stationarity of output prompted further theoretical contributions. Blanchard and Quah (1989) argue that economic shocks can be decomposed into demand and supply shocks, where the former do not have a permanent effect on output while the 


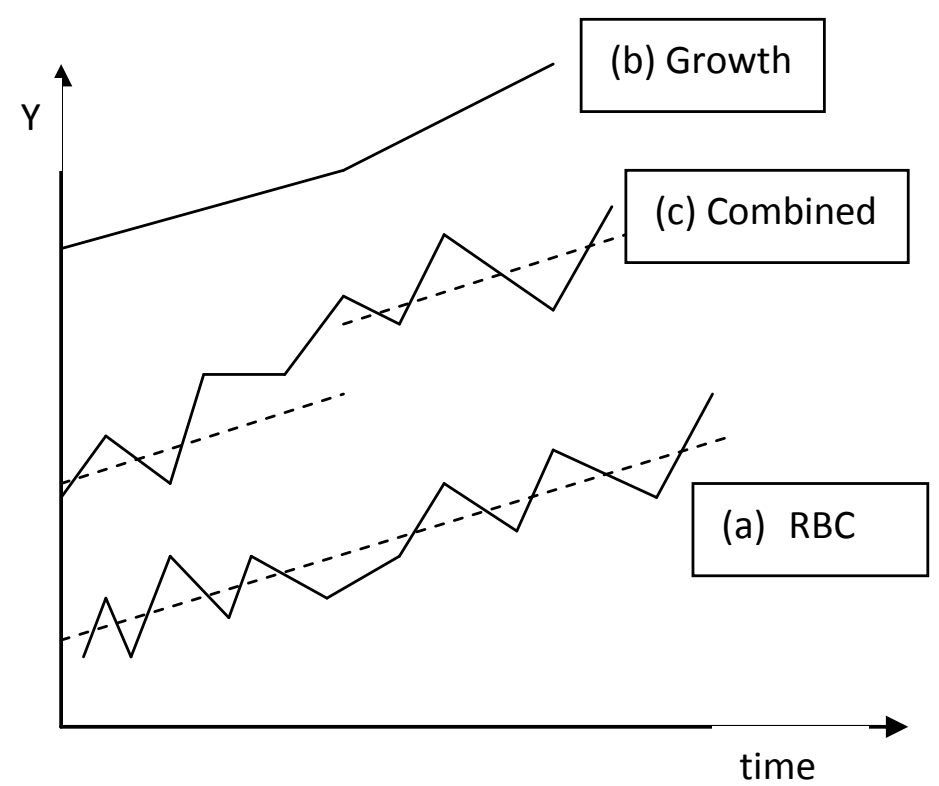

Figure 1: Stylised representation of concerns of economics schools

latter do. They show using postwar $U S$ data of output and unemployment that supply and demand shocks influence unemployment the way that a textbook AS/AD model would prescribe. Stadler (1990) goes one step further and proposes that in a monetary model with endogenous technical change even demand shocks, in form of monetary policy, will have a permanent impact on output. In contrast, Comin and Gertler (2006) propose a real business cycle model with endogenous technical change where supply shocks (a wage markup shock in their case) generate not only short run but also medium run fluctuations. This makes the classic source of business cycle fluctuations, technology shocks, endogenous.

Endogenous technological development has been employed in dynamic general equilibrium models for quite some time now, in the field of endogenous growth literature. A complete survey is beyond the scope of this paper. Endogenous growth models are characterised by allowing continued growth of economic variables without facing decreasing returns on any of these. This means that the marginal return to capital is not allowed to fall even when the labour force does not grow. This is achieved by having labour augmenting technical progress, which is endogenously determined and grows at the steady state rate of all variables.

One way to achieve this is by having technology evolve as a result of learning-by-doing, which in its simplest form is represented by the $Y=A K$ model (Romer, 1986, models along this line). A similar type of model is obtained when technological progress is specified as the outcome of economic action by some market participants, for example R\&D or human capital accumulation (Romer, 1990). A second way to introduce endogenous 
growth is to assume that productive government spending, which is growing with output, provides the growing technology needed to prevent the marginal product of capital from falling (Barro, 1990). A change in government spending directly affects the return to capital. Romer (2006) provides a textbook treatment of the properties of the economy for the different specifications of the endogenous growth process.

\subsection{Government Spending under the Zero Interest Bound}

The IS/LM model's prediction about the effect of government spending changes drastically when in a liquidity trap. The government spending multiplier is much higher since the interest rate does not increase. Even though the New Keynesian model does not necessarily contain money, a liquidity trap can still be introduced in the form of a zero bound on the nominal interest rate.

This inclusion of a zero bound on the nominal interest rate in DSGE models is a relatively recent phenomenon. Sine the zero bound is a restriction on monetary policy, the topic has received most attention in the literature on optimal monetary policy (Reifschneider and Williams, 2000; Eggertsson and Woodford, 2003; Nakov, 2008). The first observation is that an economy facing a liquidity trap falls into a deflationary spiral since a lack of demand, leading to falling marginal costs and deflation, cannot be countered by lower real interest rates. For an open economy Bodenstein et al. (2009) find that the effects of foreign demand shocks on the home economy are substantially stronger when the home economy is constrained by a zero bound. A general conclusion from this literature is that monetary policy should create additional inflation expectations for a period after the deflationary period so that deflation is reduced.

Christiano et al. (2009) investigate the size of the government spending multiplier under conditions when the zero bound holds. They find that in economies where the output cost of a zero bound is large, meaning where the deflationary spiral is more severe, the government spending multiplier becomes larger as well. The reason behind this is that the deflationary spiral is fuelled by a lack of demand, so that demand induced by government spending can offset this spiral. While under normal conditions government spending crowds out private consumption by raising the real interest rate, it crowds in private consumption under a zero bound by lowering the real interest rate through its weakening of the deflationary spiral. They furthermore show that the government spending multiplier under the zero bound is very sensitive to parameter changes. Finally, they show that in a linear model the effect does not differ between a situation where the economy hits the zero bound or where the interest rate is held fixed, since in both situations the effect of government spending on the change in the real interest rate will be the same. 
Both Christiano et al. (2009) as well as Cogan et al. (2010) estimate government spending multipliers using estimated medium scale DSGE models where the interest rate is held fixed for 2 years. Using the simulated model of the US economy by Smets and Wouters (2007), Cogan et al. (2010) find an output multiplier of unity on impact when subjecting the model to a permanent government spending shock. Christiano et al. (2009) subject the model by Altig et al. (2005) to government spending shocks of varying length. When the shocks duration is one year, the multiplier is just above unity. A duration of 8 periods gives an impact multiplier of above two, while a shock of 24 periods gives an impact multiplier of only 0.5 .

These results on government spending multipliers under a zero bound using theoretic models shows that they are sensitive to both the duration of the spending increase as well as to the model's parameters. The reason lies in that future government spending creates inflation expectations, which is very important in a liquidity trap. Unfortunately, as Christiano et al. (2009) state, empirical evidence on government spending multipliers in a liquidity trap does not yet exist and could be impossible to come by.

\section{The Model}

This section presents a New Keynesian model, which is standard in all respects except for the fact that technology growth is endogenous. This technology growth is modelled in the spirit of Comin and Gertler (2006), even though I employ a simpler specification.

\subsection{Investment Demand in Endogenous Growth Models}

In the textbook Solow growth model household saving is the primary determinant of investment and the rate of growth. This is no different in endogenous growth models. Installed capital delivers a certain rate of return, which households use in their savings decision, thereby providing funds for investment. Therefore, a higher interest rate will increase savings and growth.

The fact that a higher interest rate set by the central bank increases investment runs against the intuition of New Keynesian models. One would expect the reverse to occur, since a higher interest rate increases the required return to capital and therefore lowers the required future capital stock. However, this logic is not present an the endogenous growth model of the type of Romer (1986), since installed capital on the aggregate does not face diminishing returns. This is crucial for steady state endogenous growth, but leads to strange results when looking at deviations from a steady state, from a New Keynesian perspective. Therefore, the challenge is to construct a knowledge creation process that 
allows constant returns to capital on the steady state growth path but allows decreasing returns when dealing with deviations from that steady state path.

\subsection{The Endogenous Growth Specification}

The knowledge creation process is a learning-by-doing specification and is given by

$$
\begin{aligned}
& T_{t+1}=B X_{t}^{\eta_{1}} T_{t}^{\left(1-\eta_{1}\right)} \varepsilon_{t}^{T}, \\
& \text { with } \\
& \qquad X_{t}=K_{t}^{\eta_{2}} Y_{t}^{\left(1-\eta_{2}\right)} .
\end{aligned}
$$

$T$ is the level of technology used in a Cobb-Douglas production function (specified in Section 3.4). $B$ is a scaling parameter, $X$ is the level of economic activity relevant for learning-by-doing, $K$ is the capital stock, $Y$ is output and $\eta_{1}$ and $\eta_{2}$ are parameters which will be explained in more detail later.

Defining the gross growth rate of technology by $g_{t+1}=\frac{T_{t+1}}{T_{t}},(1)$ can be rewritten as

$$
g_{t+1}=\frac{T_{t+1}}{T_{t}}=B\left(\frac{K_{t}}{T_{t}}\right)^{\eta_{1} \eta_{2}}\left(\frac{Y_{t}}{T_{t}}\right)^{\eta_{1}\left(1-\eta_{2}\right)} e^{\varepsilon_{t}^{T}} .
$$

An inspection of (3) reveals that given a steady state level of $\frac{K}{T}$ and $\frac{Y}{T}$, technology growth will also be constant. Therefore, it fulfills the requirement for providing endogenous growth. At the same time, it should be clear that a change in capital does not lead to a one-to-one change in technology, thereby allowing decreasing returns to capital in the short run.

While the technology specification (1) looks ad-hoc, it isn't. Romer (2006) shows in a textbook treatment the endogenous growth properties of a technology accumulation function of the general form

$$
\dot{A}(t)=B\left[a_{K} K(t)\right]^{\beta}\left[a_{L} L(t)\right]^{\gamma} A(t)^{\theta}
$$

where $a_{K}$ and $a_{L}$ are the proportions of the resource used in knowledge production, $A$ is technology, and $K$ and $L$ are capital and labour. Romer (2006) also treats the case of learning-by-doing, where labour and capital is not deliberately used in knowledge production, thus having $a_{K}=a_{L}=1$, and shows that the endogenous growth properties do not change. ${ }^{2}$ A close inspection reveals that the knowledge creation function (1) is simply a discrete time special case of (4) with according parameter restrictions. Furthermore,

\footnotetext{
${ }^{2}$ This should be no surprise as technically the $a_{K}$ and $a_{L}$ terms go into the scaling parameters of the production and the knowledge accumulation function.
} 
Comin and Gertler (2006) use a similar knowledge creation function where last period's technology also determines knowledge.

In steady state all growing variables grow at rate $g$. All growing variables are therefore represented in terms of $T$ in order to be able to analyse deviations from steady states using the usual methodology.

\subsection{Source and Strength of Endogenous Growth}

The knowledge creation function (1) contains two parameters $\eta_{1}$ and $\eta_{2}$ which determine the strength and the source of endogenous growth. Romer (1986) uses capital as the source for learning by doing, therefore implying $\eta_{2}=1$. In such a case path dependence of economic variables is determined by deviations of investment from steady state. A temporary fall in investment will lower the capital/technology ratio and thus technological progress, thereby leading to a negative level effect for all growing variables. On the other hand, the case of $\eta_{2}=0$ implies that output is the source for learning by doing. This means that, next to capital, variations in labour supply cause a path dependence of the economy. As Section 5 will show, this specification will lead to stronger permanent effects of temporary shocks that affect labour demand or supply. This paper will illustrate the effects of choosing $\eta_{2}=0$ as well as $\eta_{2}=1$ as extreme cases. However, any choice of $\eta_{2}$ is possible.

Setting $\eta_{1}=0$ transforms the model to an exogenous growth model, growing at rate $B$. Due to the easy implementation of this case this will be the benchmark specification in the simulations in Section 5. The opposing case would be $\eta_{1}=1$. In this case, current technology level depends on past periods capital stock or output. Given capital stock as a source of endogenous growth $\left(\eta_{2}=1\right)$, this case comes quite close to the Romer (1986) AKL model under the assumption that used capital takes one period to become general knowledge. However, simulations with $\eta_{1}=1$ produced a wave pattern in the impulse response function, hinting at an instability, probably due to the weak investment demand present in such a model. Therefore, I will use $\eta_{1}=0.5$ as an illustrative case for an endogenous growth model. Varying the degree of $\eta_{1}$ changes the relative size of path dependence of the economy. The exact determination of $\eta_{1}$ and $\eta_{2}$ is an empirical question.

\subsection{Firms}

The production function for firm $i$ in period $t$ is specified as a Cobb-Douglas function

$$
Y_{t}^{i}=A\left(K_{t}^{i}\right)^{\alpha}\left(L_{t}^{i}\right)^{1-\alpha} G_{t}^{\gamma} T_{t}^{1-\alpha-\gamma} e^{\varepsilon_{t}^{A}}
$$


The variables $Y_{t}^{i}, K_{t}^{i}$ and $L_{t}^{i}$ represent output, capital and employment, respectively. $G_{t}$ is productive government spending and is not firm-specific. $A_{t}$ is a productivity shift parameter and $\varepsilon^{A}$ is a productivity shock. Furthermore, $T_{t}$ is defined in Section 3.2, eq. (1), and is also not firm-specific.

Aggregating across all identical firms and dividing by $T$, we obtain

$$
\frac{Y_{t}}{T_{t}}=A\left(\frac{K_{t}}{T_{t}}\right)^{\alpha} L_{t}^{1-\alpha}\left(\frac{G_{t}}{T_{t}}\right)^{\gamma} e^{\varepsilon_{t}^{A}}
$$

This shows that, given government spending is growing with $T$ in a steady state, and given a steady state labour supply, output relative to $T$ will also be in a steady state. In equation (18) I propose a government spending rule where steady state spending is a constant share of output, thus fulfilling this condition.

Each firm i minimises costs $r_{t}^{k} K_{t}^{i}+w_{t} L_{t}^{i}$ subject to output produced. The variables $r_{t}^{k}$ and $w_{t}$ represent the return on capital in use and the wage rate, respectively, in period $t$. The firm takes $r_{t}^{k}$ and $w_{t}$ as given. Solving the Lagrangian and interpreting the Lagrange multiplier as real marginal cost $m c_{t}$, the first order conditions solve for:

$$
\begin{aligned}
& r_{t}^{k}=m c_{t} \alpha \frac{Y_{t}^{i}}{K_{t}^{i}} \\
& w_{t}=m c_{t}(1-\alpha) \frac{Y_{t}^{i}}{L_{t}^{i}}
\end{aligned}
$$

Aggregating across all identical firms, equations (7a) and (7b) become

$$
\begin{aligned}
r_{t}^{k} & =m c_{t} \alpha A\left(\frac{K_{t}}{T_{t}}\right)^{-(1-\alpha)} L_{t}^{1-\alpha}\left(\frac{G_{t}}{T_{t}}\right)^{\gamma} e^{\varepsilon_{t}^{A}} \\
\frac{w_{t}}{T_{t}} & =m c_{t}(1-\alpha) A\left(\frac{K_{t}}{T_{t}}\right)^{\alpha} L_{t}^{-\alpha}\left(\frac{G_{t}}{T_{t}}\right)^{\gamma} e^{\varepsilon_{t}^{A}} .
\end{aligned}
$$

Equation (8a) shows that the steady state return to capital will be constant given that $\frac{K}{T}$, $\frac{G}{T}$ and $L$ are constant in steady state, thus fulfilling the conditions for endogenous growth. It furthermore shows that productive government spending will increase the return to both capital and labour, since it increases output without receiving factor payment.

Substituting away labour from (8a) and (8b) yields the equation for real marginal costs

$$
m c_{t}=\frac{\left(r_{t}^{k}\right)^{\alpha}\left(\frac{w_{t}}{T_{t}}\right)^{1-\alpha}}{A\left(\frac{G_{t}}{T_{t}}\right)^{\gamma} \alpha^{\alpha}(1-\alpha)^{1-\alpha} e^{\varepsilon_{t}^{A}}} .
$$

I assume, without explicitly deriving it, a standard set-up of monopolistic competition 
where firms face a finite elasticity of demand and absent of rigidities set their price at a desired mark-up $\mu>1$ above nominal marginal costs. I introduce Calvo (1983) price rigidities, where a fraction $\phi$ cannot reset its price optimally in a certain period. Therefore, the aggregate mark-up in the economy does not necessarily equal the desired mark-up, so that real marginal costs can differ from their flexible price level. For a detailed derivation, see for example Woodford (2003).

Higher marginal costs will lead to higher inflation $\pi$, as shown by the New Keynesian Phillips curve.

$$
\hat{\pi}_{t}=\beta \hat{\pi}_{t+1}+\chi \widehat{m c}_{t}
$$

where $\chi=\frac{(1-\phi)(1-\beta \phi)}{\phi}, \phi$ is the percentage of firms not re-optimising their price, $\beta$ is the time discount factor and $\hat{x}$ denotes the percentage deviation of a variable $x$ from its steady state value.

\subsection{Households}

The representative household maximises its intertemporal utility over consumption $C$ and leisure $\Lambda$ subject to a budget constraint and a capital accumulation equation. This can be specified as follows:

$$
\max _{C, \Lambda} \sum_{t=0}^{\infty} \beta^{t} u_{t}(C, \Lambda)
$$

where $\beta<1$ is the time discount factor.

I restrict attention to the commonly used CES function with log-utility for consumption. I furthermore use the common specification of introducing labour supply $L$ directly in the utility function, where $L=1-\Lambda$ when I normalise total available time to unity. I thus obtain

$$
u_{t}=e^{\left(\varepsilon_{t}^{C}\right)}\left(\log \left(C_{t}\right)-\frac{L_{t}^{1+\sigma}}{1+\sigma}\right)
$$

where $\sigma>0$ is the inverse of the intertemporal elasticity of labour supply and $\varepsilon_{t}^{C}$ is a preference shock.

Utility is maximised subject to the budget constraint and the capital accumulation identity

$$
\begin{aligned}
w_{t} L_{t}+R_{t-1} B_{t} / P_{t}+r_{t}^{k} K_{t}+\kappa_{t} & \geq C_{t}+B_{t+1} / P_{t}+I_{t}+\tau_{t} \\
K_{t+1} & =(1-\delta) K_{t}+I_{t}-\frac{\sigma_{I}}{2}\left(e^{\varepsilon_{t}^{I}} \frac{I_{t}}{K_{t}}-\overline{\left(\frac{I}{K}\right)}\right)^{2} K_{t},
\end{aligned}
$$


where $\kappa_{t}$ are profits from firm ownership of households and $\tau_{t}$ are lump sum taxes. $R_{t-1}$ is the gross nominal interest rate for bonds held from period $t-1$ to $\operatorname{period}^{3} t$ and $\delta$ is the capital depreciation rate. $C_{t}$ is consumption, $I_{t}$ is investment, $P_{t}$ is the price level and $B_{t}$ is the stock of bonds in period $t$. As usual in the New Keynesian literature, I introduce quadratic capital adjustment cost in deviation from the steady state investment-capital ratio, which is given by $\frac{I}{K}=(g-1)+\delta \cdot e^{\varepsilon_{t}^{I}}$ is a shock to the costs of investment.

Household optimisation leads to the following first order conditions:

$$
\begin{aligned}
C_{t} & =C_{t+1} \frac{1}{\beta} \frac{\pi_{t+1}}{R_{t}} e^{\varepsilon_{t}^{C}-\varepsilon_{t+1}^{C}} \\
r_{t+1}^{k} & =\frac{R_{t}}{\pi_{t+1}} \frac{1}{1-\sigma_{I} e^{\varepsilon_{t}^{I}}\left(e^{\varepsilon_{t}^{I}} \frac{I_{t}}{K_{t}}-\overline{\left(\frac{I}{K}\right)}\right)}-\frac{1-\delta+\frac{\sigma_{I}}{2}\left(\left(e^{\varepsilon_{t+1}^{I}} \frac{I_{t+1}}{K_{t+1}}\right)^{2}-{\overline{\left(\frac{I}{K}\right)^{2}}}^{2}\right.}{1-\sigma_{I} e^{\varepsilon_{t+1}^{I}}\left(e^{\varepsilon_{t+1}^{I}} \frac{I_{t+1}}{K_{t+1}}-\overline{\left(\frac{I}{K}\right)}\right)} \\
w_{t} & =L_{t}^{\sigma} C_{t}
\end{aligned}
$$

Equation (14a) is the standard Euler equation, showing the intertemporal consumption path depending on the real interest rate on bonds, $\frac{R}{\pi}$, as well as a preference shock $\varepsilon_{t}^{C}-\varepsilon_{t+1}^{C}$. Equation (14b) relates the return to capital to the real interest rate. Without capital adjustment costs, $\sigma_{I}=0$, the return on capital net of depreciation equals the real interest rate. Current higher investment increases required next period's return to capital due to the cost incurred of installing the capital. Higher future cost of installing capital lowers required return. The intuition is indirect since more installed capital in period $t+1$ will lower future adjustment costs. An investment shock (a positive $\varepsilon_{t}^{I}-\varepsilon_{t+1}^{I}$ ) raises the required return to capital, thereby lowering investment. The last condition shows the equality between the marginal utility of consumption and leisure, where the relative price of leisure in terms of consumption is the real wage.

\subsection{Equilibrium}

The full model is a collection of above equations as well as the resource constraint.

$$
\begin{aligned}
\frac{Y_{t}}{T_{t}} & =\frac{C_{t}}{T_{t}}+\frac{I_{t}}{T_{t}}+\frac{G_{t}}{T_{t}} \\
\frac{Y_{t}}{T_{t}} & =A\left(\frac{K_{t}}{T_{t}}\right)^{\alpha} L_{t}^{1-\alpha}\left(\frac{G_{t}}{T_{t}}\right)^{\gamma} e^{\varepsilon_{t}^{A}} \\
\frac{C_{t}}{T_{t}} & =\frac{C_{t+1}}{T_{t+1}} g_{t+1} \frac{1}{\beta} \frac{\pi_{t+1}}{R_{t}} e^{\varepsilon_{t}^{C}-\varepsilon_{t+1}^{C}} \\
\frac{I_{t}}{T_{t}} & =\frac{K_{t+1}}{T_{t+1}} g_{t+1}-(1-\delta) \frac{K_{t}}{T_{t}}
\end{aligned}
$$

\footnotetext{
${ }^{3}$ This timing is also used in Smets and Wouters (2003) and Galí et al. (2007).
} 


$$
\begin{aligned}
g_{t+1} & =B\left(\frac{K_{t}}{T_{t}}\right)^{\eta_{1} \eta_{2}}\left(\frac{Y_{t}}{T_{t}}\right)^{\eta_{1}\left(1-\eta_{2}\right)} e^{\varepsilon_{t}^{T}} \\
\frac{K_{t}}{T_{t}} & =\frac{\alpha}{1-\alpha} L_{t} \frac{w_{t}}{T_{t}} \frac{1}{r_{t}^{k}} \\
r_{t+1}^{k} & =\frac{R_{t}}{\pi_{t+1}} \frac{1}{1-\sigma_{I} e^{\varepsilon_{t}^{I}}\left(e^{\varepsilon_{t}^{I} \frac{I_{t}}{K_{t}}}-\overline{\left(\frac{I}{K}\right)}\right)}-\frac{1-\delta+\frac{\sigma_{I}}{2}\left(\left(e^{\varepsilon_{t+1}^{I}} \frac{I_{t+1}}{K_{t+1}}\right)^{2}-\overline{\left(\frac{I}{K}\right)^{2}}\right)}{1-\sigma_{I} e^{\varepsilon_{t+1}^{I}}\left(e^{\varepsilon_{t+1}^{I}} \frac{I_{t+1}}{K_{t+1}}-\overline{\left(\frac{I}{K}\right)}\right)} \\
\frac{w_{t}}{T_{t}} & =L_{t}^{\sigma} \frac{C_{t}}{T_{t}} \\
m c_{t} & =\frac{\left(r_{t}^{k}\right)^{\alpha}\left(\frac{w_{t}}{T_{t}}\right)^{1-\alpha}}{A\left(\frac{G_{t}}{T_{t}}\right)^{\gamma} \alpha^{\alpha}(1-\alpha)^{1-\alpha} e^{\varepsilon_{t}^{A}}}
\end{aligned}
$$

The New Keynesian Phillips curve (10) translates marginal costs to inflation. All that is needed to close the model are the policy processes for the interest rate, government spending and taxes.

\subsection{Policy}

The central bank follows a Taylor rule to determine the notational interest rate.

$$
R_{t}^{n o t}=R^{*}+\rho_{\pi}\left(\pi_{t}-\bar{\pi}\right)+\rho_{y}\left(\frac{\frac{Y_{t}}{T_{t}}-\overline{\left(\frac{Y}{T}\right)}}{\overline{\left(\frac{Y}{T}\right)}}\right)+\varepsilon_{t}^{R},
$$

where $R^{*}$ is the target rate implied by the steady state return to capital, $\bar{\pi}$ is the target inflation rate, and $\overline{\left(\frac{Y}{T}\right)}$ is the target output-technology ratio. The inclusion of the output gap in this manner follows Kühn and Muysken (2009) and allows a simple linearisation around the steady state.

The actual interest rate is determined by

$$
R_{t}=\max \left(0, R_{t}^{n o t}\right)
$$

This introduces a non-linearity into the model, as sometimes the interest rate setting might be restricted by the zero bound. This requires special attention in the solution procedure, shown in Appendix A.

The government finances all its spending using lump-sum taxation. Government spending on the steady state growth path is a fraction $\theta$ of output. $\varepsilon_{t}^{G}$ is a shock to government spending.

$$
\frac{G_{t}}{T_{t}}=\left(\theta \frac{Y}{T}\right) e^{\varepsilon_{t}^{G}}
$$


The absence of a time subscript on $\frac{Y}{T}$ is deliberate. This specification implies that government spending does not fluctuate with output when it moves away from its steady state level, but is allowed to grow with output at the steady state pace. When written in a form as deviation from steady state, one obtains a standard formulation of the spending process.

\subsection{Steady State}

In steady state, $m c=1 / \mu$ holds. Furthermore, time subscripts can be dropped. From the Euler equation (imposing steady state $\frac{C}{T}$ ) and the equality of net returns to capital and bonds one can obtain

$$
g-1+\delta=\beta r^{k}-(1-\beta)(1-\delta)
$$

Furthermore, steady state investment is

$$
\frac{I}{T}=\frac{K}{T}(g-1+\delta)
$$

Additionally, 7a shows that

$$
r^{k}=\frac{\alpha}{\mu} \frac{Y}{T}\left(\frac{K}{T}\right)^{-1}
$$

Steady state consumption is

$$
\frac{C}{T}=(1-\theta) \frac{Y}{T}-\frac{I}{T}
$$

Steady state output is given by

$$
\frac{Y}{T}=\left(A \theta^{\gamma}\left(\frac{K}{T}\right)^{\alpha} L^{1-\alpha}\right)^{\frac{1}{1-\gamma}}
$$

Combining (8b) and (14c) one obtains steady state labour supply

$$
L=\left[\frac{\left(\frac{1-\alpha}{1-\gamma} \frac{1}{\mu}\right)^{1-\gamma} A \theta^{\gamma}\left(\frac{K}{T}\right)^{\alpha}}{\left(\frac{C}{T}\right)^{1-\gamma}}\right]^{\frac{1}{\sigma+\alpha-\gamma(1+\sigma)}} .
$$

To determine the steady state, one has to analyse the labour supply - growth tradeoff, as described in Turnovsky (2000). A precise solution can be derived using equations (19a) 
to $(19 \mathrm{f})$ when regarding $\frac{K}{T}(1-\beta)(1-\delta) \approx 0$. This solves to

$$
L \approx\left(\frac{\frac{1-\alpha}{\alpha} \frac{1}{\beta}}{\frac{(1-\theta) \mu}{\alpha \beta}-1}\right)^{\frac{1}{1+\sigma}}
$$

The return to capital is then determined, using labour supply, by the equation

$$
\left(\frac{\beta\left(1+r^{k}-\delta\right)}{B}\right)^{\frac{1-\alpha}{\alpha+(1-\alpha) \eta_{2}}}\left(r^{k}\right)^{\eta_{1}}=\left(\frac{\alpha}{\mu}\right)^{\eta_{1}}\left(A \theta^{\gamma} L^{1-\alpha}\right)^{\frac{\eta_{1}}{\alpha+(1-\alpha) \eta_{2}}}
$$

Using (19a), this translates directly into growth. When $\eta_{1}=0, g=B$ holds, consistent with an exogenous growth rate. When $\eta_{1}>0$, all other factors influence the return to capital and thus growth is determined endogenously.

\section{Methodology}

All variables shown in equations (15a) to (15i) possess a steady state. These equations are linearised around that steady state using a first order Taylor approximation. Afterwards, the model dynamics are simulated using the $P-Q$ approach. The solution strategy for the zero bound is shown in Appendix A. The simulation requires a whole range of parameters. Since the aim is to illustrate the additional value of endogenous growth, I calibrate the parameters using existing literature.

\subsection{Calibration}

I simulate the model for quarterly periods. Table 1 shows the parameters chosen to simulate the model. Most of them are standard parameters with little importance to this paper's results. While Galí et al. (2007) choose an inverse elasticity of labour supply of $\sigma=0.2$, this value is estimated by Smets and Wouters (2003) to $\sigma=2.1$. A lower parameter increases the labour supply response to shocks, and thereby increases the chances for consumption crowding-in to government spending. $\sigma=1$ is the value chosen by Linnemann and Schabert in various papers for representative purposes. The capital adjustment cost parameter is set to $\sigma_{I}=\frac{\delta}{0.06(g-1+\delta)} \approx 14$, following the logic in Christiano et al. (2009). I simulate the model with both productive and unproductive government spending to illustrate its contribution.

The price stickiness parameter is rather high. However, Hall (2009) argues that a very high degree of price stickiness is needed for a realistic variability of the mark-up. In this model, all rigidity and thus mark-up variability has to come from $\phi$, thus justifying this choice. The output parameter on monetary policy is sometimes set to zero by authors 
Table 1: Parameters

\begin{tabular}{|r|c|l|}
\hline \hline Parameter & Value & Source \\
time discount $\beta$ & 0.99 & standard \\
capital share $\alpha$ & 0.33 & standard \\
depreciation $\delta$ & 0.025 & standard \\
inverse $L^{S}$ elasticity $\sigma$ & 1 & Linnemann and Schabert (2003) \\
markup & 1.2 & standard \\
capital adj. cost $\sigma_{I}$ & $\approx 14$ & Christiano et al. (2009) \\
government share $\theta$ & 0.2 & Baxter and King (1993) \\
shock autocorrelation $\rho^{\varepsilon}$ & 0.9 & Galí et al. (2007) \\
\hline New Keynesian Parameters & \\
price stickiness $\phi$ & 0.85 & Hall (2009) \\
Taylor rule $\rho_{\pi}$ & 1.7 & Smets and Wouters (2003) \\
Taylor rule $\rho_{y}$ & 0.11 & Smets and Wouters (2003) \\
inflation target $\bar{\pi}$ & 1.005 & ECB target \\
scaling parameter $B$ & 1.006 & Comin and Gertler (2006) \\
endog. growth strength $\eta_{1}$ & $0 ; 0.5$ & \\
source of endog. growth $\eta_{2}$ & $1 ; 0$ & \\
government prod $\gamma$ & $0 ; 0.1$ & Romp and de Haan (2007) \\
\hline \hline
\end{tabular}

that try to show crowding-in of consumption (Linnemann and Schabert, 2003; Galí et al., 2007). The reason is simply that higher interest rates lower consumption demand. I will use the parameters found by Smets and Wouters (2003), but I will also show the effect of having a strong reaction to the output gap by using $\rho_{y}=0.5$.

There is no reference paper for the technology evolution function. I set $B=1.006$ to obtain a steady state growth of $2.1 \%$ in the exogenous growth model (used in Comin and Gertler, 2006). I furthermore use this steady state growth rate to define the steady state values of $r^{k}, Y / T$ and so forth. This implicitly defines A, since A scales the model's return to capital and steady state growth (see (21)). I simulate the model for exogenous growth $\left(\eta_{1}=0\right)$ as well as for endogenous growth $\left(\eta_{1}=0.5\right)$. This value is arbitrary. However, this model's results are not sensitive to the exact choice of $\eta_{1}$. Section 5.6 shortly discusses the implication of $\eta_{1}=0.1$. Different sources of endogenous growth, output or capital, are also shown using $\eta_{2}=0$ and $\eta_{2}=1$. Any intermediate combination is possible as well, with predictable results.

Finally, I specify that shocks $\varepsilon^{x}$ develop according to the process

$$
\varepsilon_{t}^{x}=\rho^{\varepsilon} \varepsilon_{t-1}^{x} \quad x \in[A, G, C, I, T],
$$

where I use an autocorrelation coefficient for shocks of $\rho^{\varepsilon}=0.9$. For the interest rate 
shock the interest rate is set discretely to $1 \%$ below steady state for one year. When simulating the effect of government spending while the zero bound on the interest rate holds, I set government spending to a $10 \%$ increase for the duration of 4 quarters while holding the interest rate fixed.

\subsection{Analysed Scenarios}

I present a number of scenarios in order to highlight the valuable additions endogenous growth makes to a New Keynesian model. The first two scenarios (Section 5.1) are meant to illustrate in what way the New Keynesian model changes when endogenous growth is introduced. To that aim I simulate a negative investment shock, an increase in capital adjustment $\operatorname{costs} \varepsilon_{t}^{I}$, as well as a negative research shock, a fall in $B$.

In Section 5.2, I show the consumption crowding-in potential of the New Keynesian endogenous growth model. To that aim, I introduce a government spending shock, $\varepsilon_{t}^{G}$, in the size of $2 \%$ of GDP. I furthermore show the impact of having productive government spending by applying the government spending shock when spending is unproductive $(\gamma=0)$ and productive $(\gamma=0.1)$.

Section 5.3 shows that monetary policy has not only short run but also long run consequences in a New Keynesian endogenous growth model. To that aim, I first subject the model to a simple interest rate shock, where the nominal interest rate is set at $1 \%$ below its steady state value for 1 year. Afterwards, I show the short and long run consequences of alternative monetary policy rules in face of a negative productivity shock. This requires the simulation of a negative productivity shock $\left(\varepsilon_{t}^{A}\right)$ with a Taylor rule parameter on output of $\rho_{y}=0.11$ (baseline) as well as $\rho_{y}=0.5$

In a liquidity trap monetary policy looses its power to influence the economy. I simulate the effect of such a liquidity trap by subjecting the model to a simultaneous negative investment $\left(\varepsilon_{t}^{I}\right)$ and consumption $\left(\varepsilon_{t}^{C}\right)$ shock (Section 5.4). This lowers demand so much that deflation occurs and the nominal interest rate should be set at a below zero value. In this case, the zero interest rate becomes binding. I show the net effect of this zero bound by subtracting the response of the economy with a zero bound from the response when monetary policy could set below zero interest rate, thus follow the Taylor rule normally. I furthermore show the effect of government spending in the presence of a zero bound. Due to the linearity of our model, I can simulate this as a discrete government spending shock of $2 \%$ of GDP for 4 quarters while holding the nominal interest rate fixed.

The final case studied in Section 5.5 concerns the paradox of thrift. I introduce a savings shock, in form of a negative consumption preference shock $\left(\varepsilon_{t}^{C}\right)$. I will show that such a shock can reduce demand so far that investment actually falls. 


\section{Results}

I present the effect of a shock as a percentage deviation to a scenario without a shock occurring. I therefore calculate the path of the actual growing variables by multiplying with $T$, and then by taking the percentage deviation to a baseline scenario without any shocks. In this way we see long run effects caused by short run deviations in the growth rate, something which a standard New Keynesian model cannot show. All graphs show years on the x-axis and percentage deviation (output and consumption) or percentage difference (inflation, interest rate) from the baseline scenario on the y-axis.

The solid line represents the exogenous growth model, the dashed line an $A K$ type endogenous growth model where capital determines learning-by-doing, and the dotted line an endogenous growth model where output determines learning-by-doing, thus featuring the highest path dependence.

\subsection{Illustration of Exogenous versus Endogenous Growth}

The definition of an exogenous growth model is that the underlying rate of growth is determined exogenously and that any other economic fluctuations don't have an impact on the long run. In contrast, an endogenous growth model is characterised by having the rate of growth determined endogenously, so that economic fluctuations do have an impact on long run variables. This contrast is nicely illustrated by comparing a negative investment shock with a negative research shock. Figure 2 shows the response of output in these two cases.

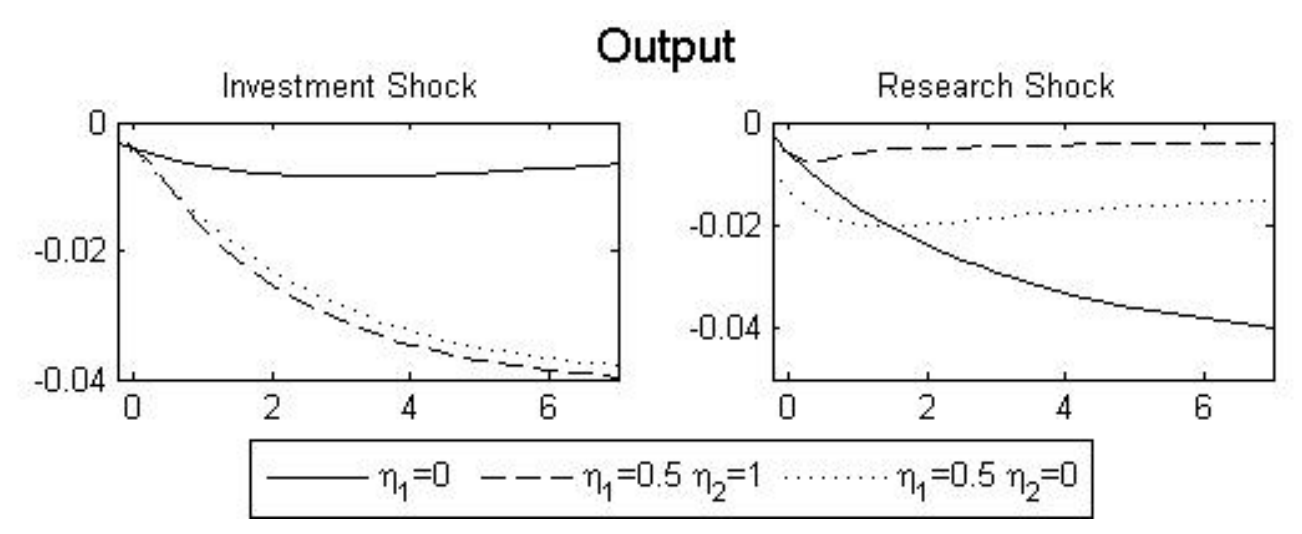

Figure 2: The response of output to an investment shock and a research shock.

The negative investment shock is introduced as a shock to cost of investment, which requires the return to capital increase, thereby lowering investment. In the exogenous growth model, it leads to a long-lasting fall in output by about half a percent. Eventually, output will return to its baseline level despite this long-lasting performance of the economy below its potential. In an endogenous growth model, the lower capital stock 
lowers learning-by-doing, and thus technological progress. Figure 2 shows the continuous decline in output. Technically, the capital technology stock is below its steady state value the whole time since the investment shock is so persistent, thereby lowering the growth rate. The response of the two sources of endogenous growth is so similar since the labour supply hardly changes, thereby making capital the driving force of learning-by-doing even in the output case.

The negative research shock is implemented as a persistent fall in $B$. In the exogenous growth model, this leads to a continuous decline in technology relative to the baseline case. Therefore, output is lost permanently, without any chance for policy to interact. In the endogenous growth model, technological progress is determined endogenously, represented by the quick stabilisation of the output path in Figure 2. Technically, the initial fall in $B$ lowers the growth rate. However, when $T$ falls, the ratio $\frac{X}{T}$ rises, thereby reinstating the original growth rate. The consequence is therefore only an initial loss in output that persists. The higher $\eta_{1}$, the larger will be the initial fall in output, and the faster will be the transition back to the steady state growth.

To conclude, the growth rate falls in an endogenous growth model, leading to a permanent loss in output, when there is a shock to the accumulation of productive resources, while in an exogenous growth model such a permanent effect has to be introduced exogenously. The following sections show that this endogenous determination of growth leaves room for policy to have permanent implications.

\subsection{Consumption Crowding-in}

Kühn et al. (2010) propose, without explicit modelling, the use of a New Keynesian endogenous growth model to obtain consumption crowding-in in response to a government spending shock. Figure 3 shows that this channel works as expected when output is the source of learning-by-doing $\left(\eta_{2}=0\right)$. The government spending shock is introduced as an autoregressive shock.

Government spending leads to an increase in demand. This increase in demand increases labour demand, which increases real wages, and thus labour supply. Furthermore, it leads to inflation, which in turn causes the central bank to increase the interest rate, reducing consumption demand. Under exogenous growth, the rise in demand by government spending has to be met by the increase in output and the fall in consumption demand, causing crowding out. Under endogenous growth, the increased economic activity causes learning-by-doing, which increases the underlying growth rate of the economy. This in turn increases consumption demand, which again raises labour demand, output and inflation. Due to higher output, consumption does not have to fall as far as under exogenous growth. 

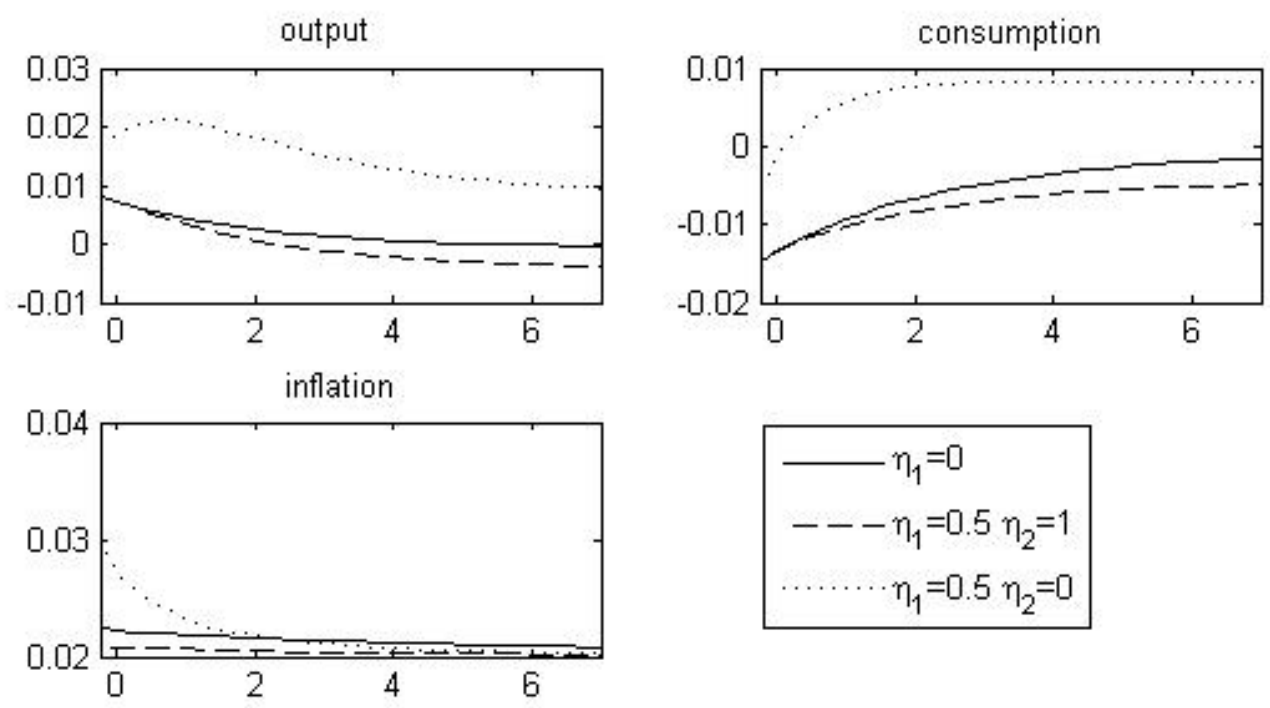

Figure 3: The response to a government spending shock using $\gamma=0$.

Kühn et al. (2010) make clear that to obtain consumption crowding-in, government spending needs to cause additional positive effects for private consumption demand. This demand is created by the higher economic activity that is caused by government spending. One can calculate the output multiplier of government spending by $m=\frac{1}{\theta} \%$, which yields an output multiplier of $m=0.93$. Furthermore, the path dependence implied by an endogenous growth model causes this increased activity to also have a positive long run effect on output.

When looking at the cases of $\eta_{1}=0$ and $\eta_{2}=1$ in Figure 3 , one can see that inflation hardly rises. The reason lies in the output response of the central bank reaction function, so that interest rates increase without large inflationary effects. This increase in the interest rate lowers investment demand and capital accumulation. Even though this effect is not large, it causes a loss in long run output when capital is the source of learning by doing.

The output multiplier for the exogenous growth model is only $m=0.41$. This is very small, due to the degree of price stickiness used. Hall (2009) shows that to obtain a multiplier close to unity, one needs a quarterly probability of sticky prices of $\phi=0.89$. This paper shows that in an endogenous growth model government spending produces more demand and thus a higher output multiplier without the need to induce a higher degree of price stickiness.

Figure 4 shows the effect of having productive government spending. The productivity effect directly increases output but also lowers marginal costs, thereby lowering the inflation effect of government spending in all cases. The output multipliers are $m=0.53$ and $m=1.02$. The main driver of consumption crowding-in is therefore the demand effect of 
government spending, and not the productivity effect.
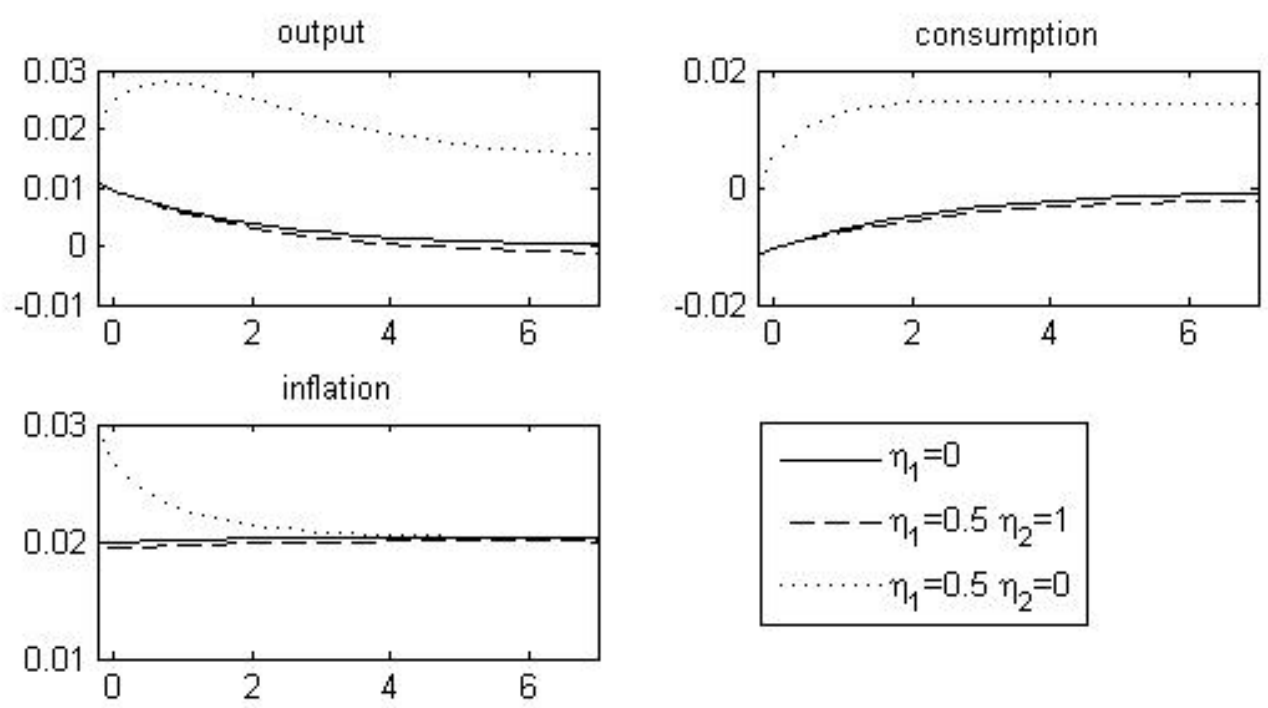

Figure 4: The response to a government spending shock using $\gamma=0.1$.

This section shows that endogenous growth effects are an important transmission channel for government spending. Not only do they increase the multiplier without the need to increase price stickiness, they also allow consumption crowding-in, a puzzle often discussed in recent literature.

Does this mean that the government should have high spending? Clearly, the drawback in this model is the absence of potential distortionary taxation. A policy prescription about optimal steady state government spending needs to take potential distortionary taxes into account. Considering government spending as a tool next to monetary policy to respond to business cycle fluctuations, the assumption of debt financed spending is realistic. Spending can be cut in times of boom and increased in recessions. When used in such situations, this section shows that government spending not only increases short run, but also long run output when learning-by-doing depends sufficiently on current economic conditions.

\subsection{Long Run Policy Implications of Monetary Policy}

A standard phrase in undergraduate textbooks is that money is neutral in the long run. The idea behind that is that in the long run output is determined by supply factors, while potential demand effects induced by money in the short run disappear through adjustments in the price level. I will show that this is only partly correct in an endogenous growth setting. While long run output is indeed determined by supply factors, these can be influenced by short run monetary policy. 


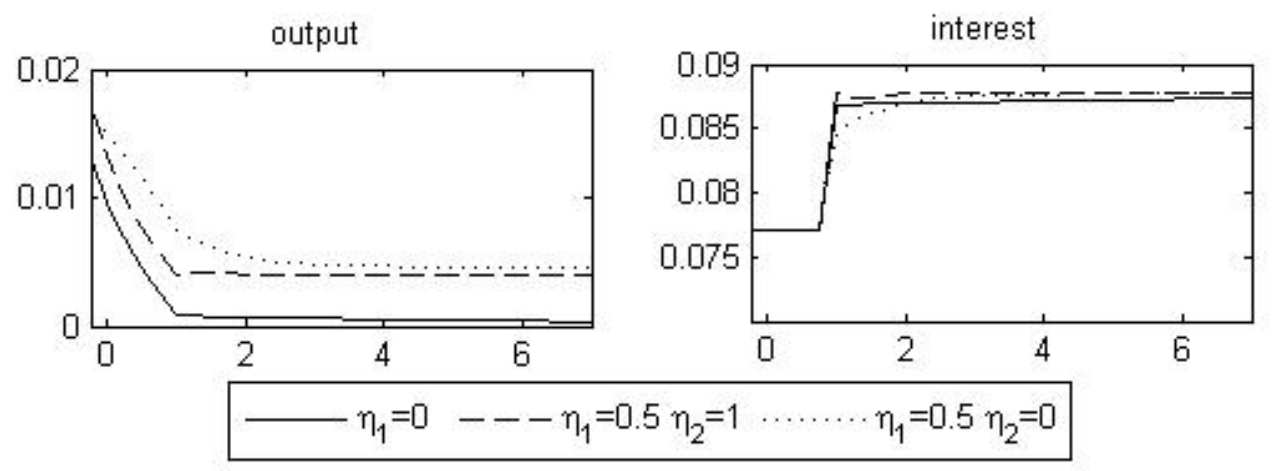

Figure 5: The response of output to a negative interest rate shock.

Figure 5 shows the response of output to the central bank setting the interest rate at $1 \%$ below steady state for one year. The lower interest rate raises both consumption and investment demand. This increases labour demand, real wages, inflation and output. Higher output as well as a higher capital stock lead via learning-by-doing to higher technology growth, and thereby lead to a permanent increase of output. This means that short run demand induced by monetary policy has real long run effects.

Rannenberg (2009) simulates an endogenous growth model with a Taylor rule and a time-varying NAIRU and claims that the inflation averse policy of European central banks following the oil price shocks of the 70's caused large increases in the NAIRU. He claims that a monetary policy rule with a larger weight on the output gap could have reduced that increase in the NAIRU and thus increased output.

Even though my model does not contain a NAIRU, I am able to reproduce the effects on long run output found by Rannenberg (2009). The model is subjected to a negative productivity shock, which reduces output given the amount of resources used and also increases marginal costs. Thus, it is similar to an oil price shock. Figure 6 shows the response of output, inflation and the interest rate to that shock.

Inflation rises for two reasons. The first is the direct increase in marginal costs of production. The second is that consumers want to smooth the temporary fall in consumption due to the temporary fall in output, thereby creating excess demand. The rise in inflation forces the central bank to increase the nominal interest rate.

In an endogenous growth model another effect gains importance. The negative productivity shock adversely affects learning-by-doing, though the effect is much stronger in the output case $\left(\eta_{2}=0\right)$. This adverse shock to growth reduces current consumption demand, which lowers excess demand and explains the lower response of inflation in the endogenous growth cases. However, the lower amount of excess demand also lowers output further. Given the presence of the output gap in the Taylor rule, the fall in output and the rise in inflation almost cancel out in the case of $\eta_{2}=0$ given our parameter set. 

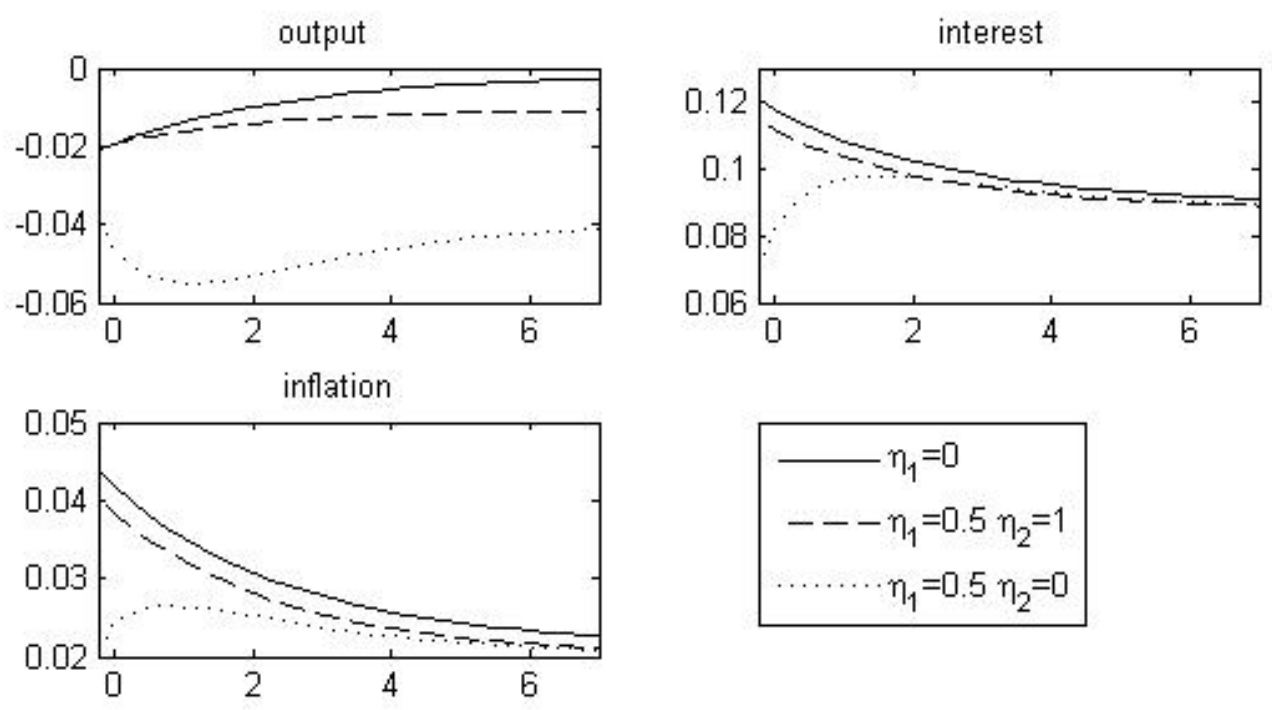

Figure 6: The response of output, inflation and the interest rate to a negative productivity shock with a monetary policy reaction of $\rho_{y}=0.1$.

Figure 6 makes clear that the adverse effect on learning-by-doing caused by the negative productivity shock has significant long run consequences for output. Rannenberg (2009) suggests that these consequences can be reduced by following a monetary policy with a larger weight on the output gap. I reproduce such a scenario in Figure 7, where I impose the same negative productivity shock but assume an output gap parameter of $\rho_{y}=0.5$ in the Taylor rule. This should partially offset the increase in interest rates due to higher inflation.
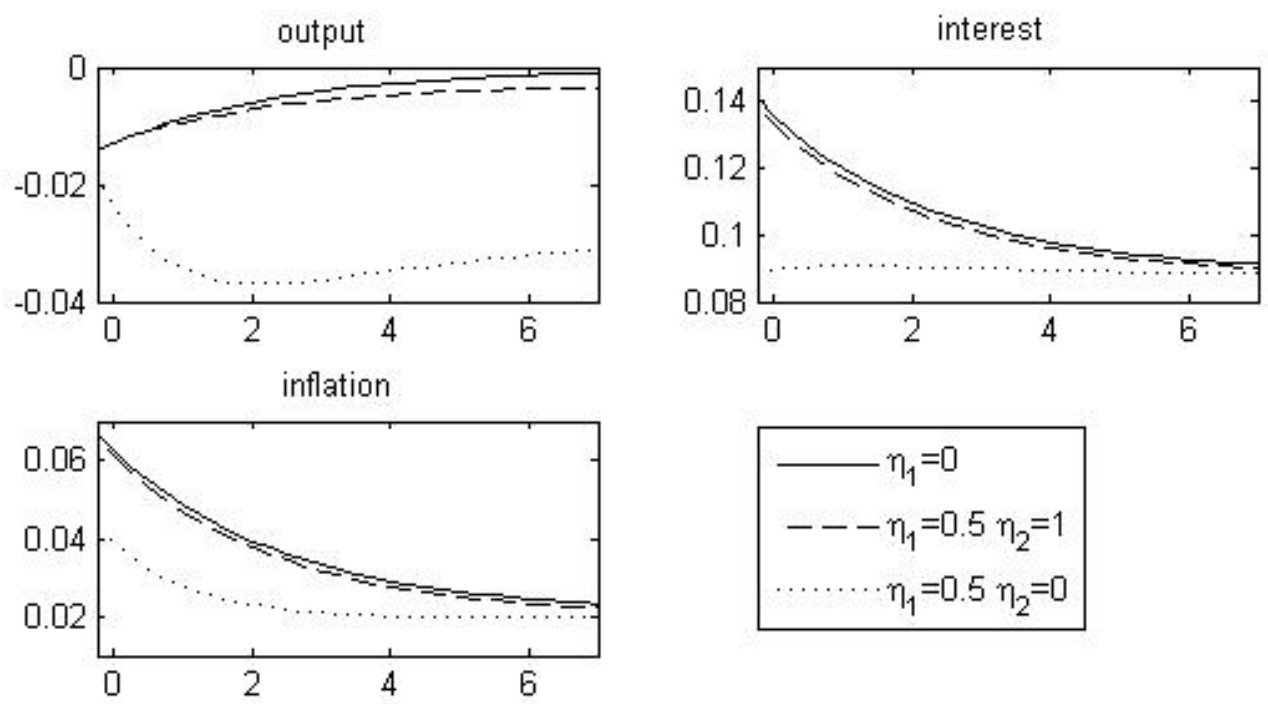

Figure 7: The response of output, inflation and the interest rate to a negative productivity shock with a monetary policy reaction of $\rho_{y}=0.5$.

The policy of lower real interest rates leads to more consumption and investment 
demand. The expected effect will be a higher inflation rate as monetary policy sets lower interest rates for any given inflation due to the negative output gap. The fact that nominal interest rates rise has to do with the strong rise in inflation. ${ }^{4}$ Higher demand also increases the output response of the economy. Thus, higher investment and higher output increase learning-by-doing and thereby lower the adverse long run consequence of the temporary fall in productivity. Therefore, we can confirm the result found by Rannenberg (2009).

The analysis of the impact of monetary policy on short and long run output suggests that short term inflationary policy is a viable tool to increase long run output. However, the purely forward looking specification of inflation implies a costless inflationary period to boost output, which might not be realistic. While low interest rates will boost output and thus learning-by-doing, the following disinflationary period might diminish these effects. Thus, this question requires further research using a richer model. The final conclusion concerning monetary policy remains unchanged: through its influence on current economic conditions monetary policy has real effects on long run variables. These should be taken into account in the pursuit of monetary policy.

\subsection{The Zero Bound: One's Losses, Other's Gains}

The recent economic crisis has brought interest rates down to very low levels, fuelling fears of a liquidity trap like Japan has seen it. At the same time, huge fiscal stimulus packages have been implemented. The literature review already pointed out that optimal monetary policy in periods of a zero bound should create additional inflation expectations to alleviate the situation. Without it, the economy faces a spiral of a shortage of demand, leading to deflation, higher real interest rates and more demand shortage.

The literature review also showed that fiscal policy in times of a zero bound is a lot more powerful due to the demand creation effect of government spending. In fact, Christiano et al. (2009) show that fiscal policy becomes more powerful in situations when the deflationary spiral of a zero bound is more severe.

I subject the model to a simultaneous negative shock to investment and consumption. This large fall in demand leads to deflation. When the nominal interest rate hits zero, monetary policy looses its power to react appropriately to the deflationary situation. The consequences are a higher real interest rate, even more loss in demand, and finally in output. Figure 8 shows the net effect of the central bank's loss in power. This is calculated as the difference between a scenario where the central bank could set below zero interest rates and a scenario where it can't.

The implications are clear. The zero bound holds for approximately one year, during

\footnotetext{
${ }^{4} \mathrm{~A}$ long-lasting negative shock in the Taylor rule will actually lead to increasing nominal interest rates. This is why we set a discretionary interest rate shock in that scenario.
} 

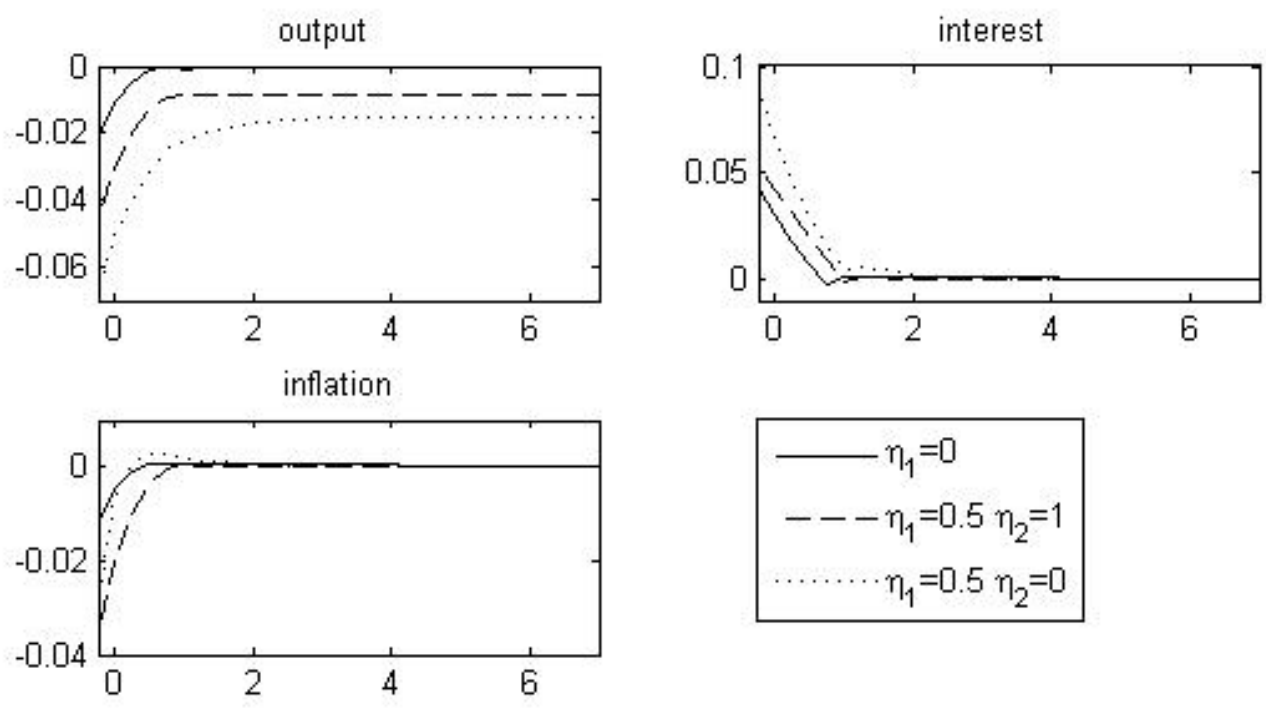

Figure 8: The net effect of output, inflation and the interest rate due to the inability of monetary policy to follow the Taylor rule in response to a simultaneous negative consumption and investment shock.

which the nominal interest rate is too high and inflation is too low. Furthermore, output as well as investment are too low. This leads to a fall knowledge accumulation due to learning-by-doing. At this point, the endogenous growth model introduces another transmission channel into the zero bound deflationary spiral. Lower growth lowers households' consumption demand, which further worsens the deflationary spiral. Figure 8 clearly shows that. Furthermore, the loss of power of monetary policy causes significant long run losses in output. Since monetary policy is not able to avert this loss, fiscal policy has to come to the rescue.

To simulate a government spending shock while a zero bound holds, I introduce it as a shock the size of $2 \%$ of GDP lasting 4 quarters while at the same time keeping the interest rate fixed, in line with the finding of Christiano et al. (2009). Figure 9 shows that the government spending shock increases inflation, thereby countering the deflationary spiral that leads to large output losses. The net effect is a very large increase in output. The government spending multipliers are $m=1.22, m=1.33$ and $m=1.57$. Notably, consumption also increases.

I showed that the loss of power of monetary policy leads to larger adverse effects in an endogenous growth model due to the additional effect of growth on consumption demand. By the same token, this channel also increases the government spending multiplier, thus confirming Christiano et al. (2009). This means that fiscal policy becomes even more important in the presence of a zero interest rate when endogenous growth effects are relevant. When comparing Figures 8 and 9 , it is striking to see that the government spending increase can actually offset the adverse consequences of the loss of power of 

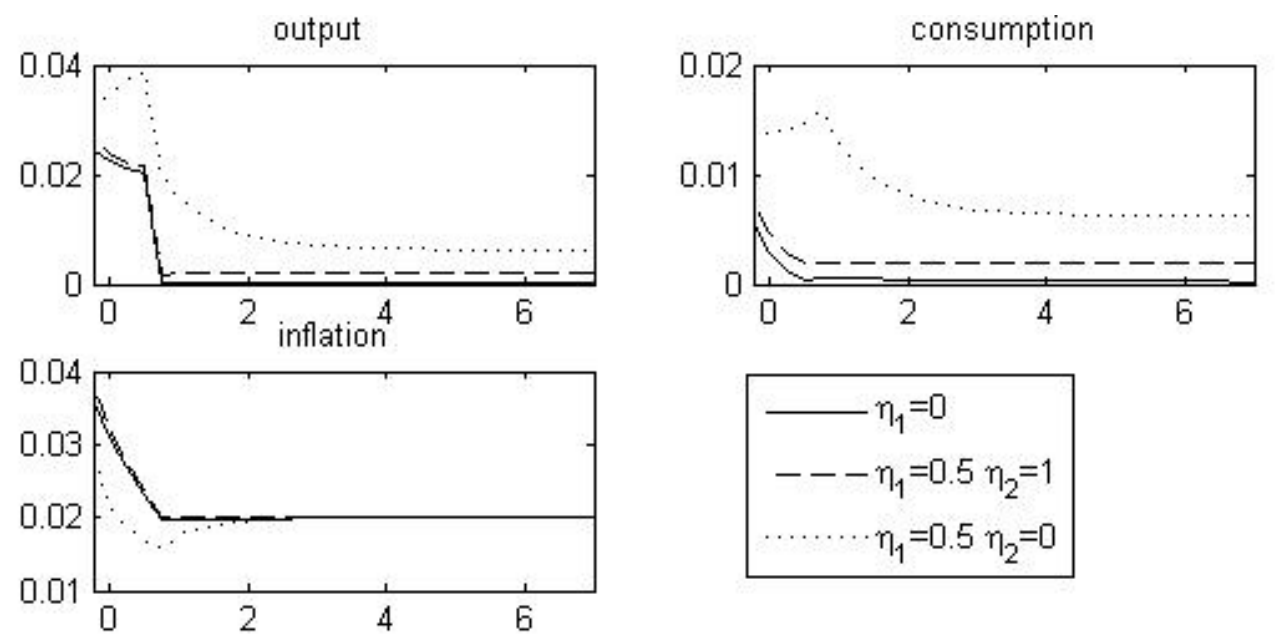

Figure 9: The response to a government spending shock in the presence of a zero bound using $\gamma=0$.

monetary policy. This shows that government spending is a very important tool in the hands of policy makers, especially in times when monetary policy becomes powerless.

\subsection{The Paradox of Thrift}

The paradox of thrift was popularised by Keynes and states that the desire of the economy as a whole to save more may be detrimental to its well-being as the fall in demand may decrease incomes so much that the economy actually saves less in the end. The primary criticism to that theory is the fact that additional savings enter the loans market, lowering the interest rate and thereby raise investment.

I introduce a savings shock as a negative time preference shock for households. Figure 10 shows that the criticism to the paradox of thrift is indeed valid: investment increases in response to such a shock. In the exogenous growth model, output temporarily falls and then rises to a level slightly above steady state due to the increased capital stock. In the long run, output will be back at its steady state level.

When learning-by-doing is determined by the capital stock, then the savings shock, by increasing investment, leads to a significant positive long run response of output. The growth rate will return to its steady state level, but output experiences a level shift.

The results change when current output is a strong determinant of the endogenous growth rate. The savings shock reduces demand, which in turn lowers output, the growth rate and leads to an even further fall in demand. These effects contribute to inducing a large initial fall of output. After a couple of periods, the output-technology ratio in the knowledge accumulation function is back at steady state, while investment is still above steady state since the savings shock is so persistent, and therefore capital, output and growth are increasing. As can be seen in Figure 10, output eventually increases above its 


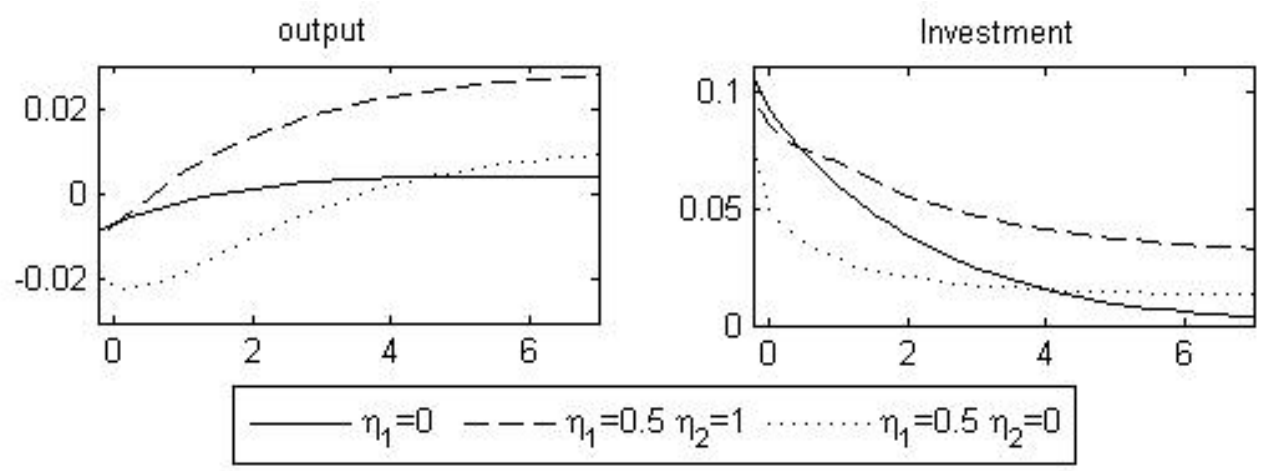

Figure 10: The response to a savings shock.

baseline level.

When I reduce the persistence of the savings shock to $\rho=0.8$, Figure 11 shows that investment actually falls due to the large adverse effect on output. The real interest rate is still below steady state, thus inducing investment. However, the resources available for investment are simply lower due to the loss in output. Therefore, I can show a real paradox of thrift, where additional savings demand in an endogenous growth model actually leads to a fall in investment, and thus an adverse effect on short run and long run output.

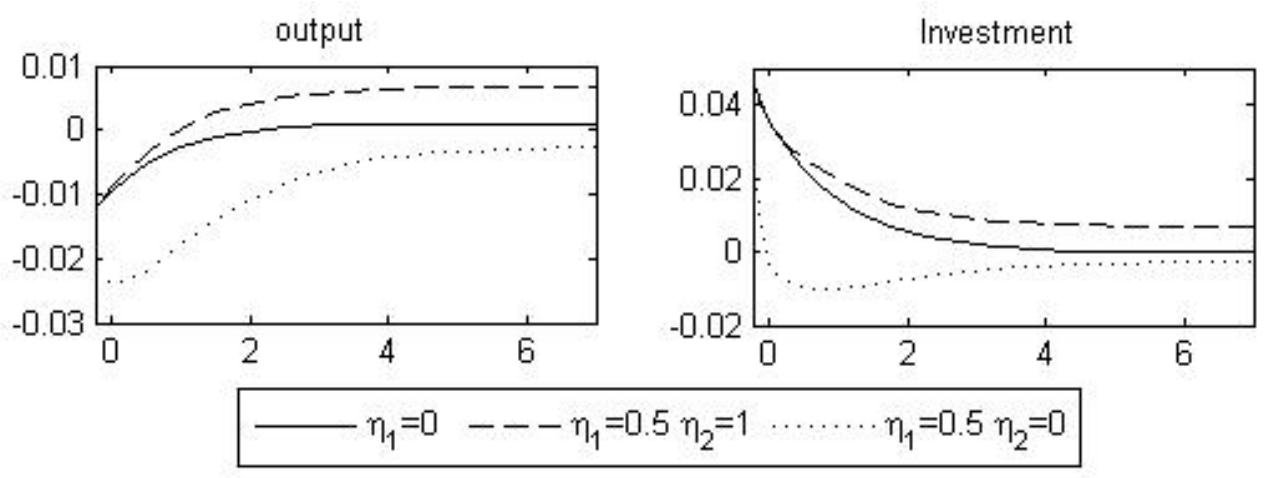

Figure 11: The response to a savings shock with persistence $\rho=0.8$.

\subsection{Robustness}

The preceding analysis implies a pretty strong impact of current economic conditions on the growth rate of technology. A $1 \%$ difference in $X$ leads to a $0.5 \%$ change in growth, and thus technology. For the case where output determines learning-by-doing $\left(\eta_{2}=0\right)$, this implies very strong effects of output on growth and thus on demand. I also simulated all cases with $\eta_{1}=0.1$. There is hardly any difference for the case where capital determines learning by doing $\left(\eta_{2}=1\right)$. Since the capital stock adjusts slowly anyways, there are never any large immediate effects. 
When $\eta_{2}=0$, changes are more apparent. The immediate impact of all shocks is smaller. The reason is that the growth rate does not react that strongly on impact, thereby lowering the second round effect from consumption demand. On the other hand, the growth rate takes longer until it reaches its steady state again. As equation 3 shows, a fall in $Y$ will lower $T$ until the ratio, and thus growth, is back at its steady state. This means that demand effects of below steady state output last longer.

Concerning the qualitative results obtained in this chapter, the only change concerns consumption crowding-in. Since the rise in output does not lead to such a strong growth effect, consumption demand is also lower. Therefore, consumption falls on impact, and we observe a J-curve effect where consumption only rises above its baseline level after 2 years. All other results, including the paradox of thrift, still hold.

\section{Conclusion}

This paper achieves a number of important goals relevant in recent research. It derives a New Keynesian endogenous growth model featuring investment demand. Current economic conditions affect the economy's growth rate. The model introduced allows a floating transition in the strength of this effect with the setting of one parameter, to range from exogenous growth to strong endogenous growth effects. Furthermore, the chapter considers two possibilities for the determination of technological progress: learning-by-doing from capital usage or from total production.

Endogenous growth adds two important channels to the standard New Keynesian model. The first is that temporary shocks or policy measures can have permanent effects. The second is that temporary deviations in the growth rate have an immediate effect on consumption demand. This causes similar sized shocks to have a larger immediate effect in an endogenous growth model than in an exogenous growth model.

The most important impact of these new transmission channels is the fact that government spending crowds in private consumption. While other authors have tried to construct a New Keynesian model that can achieve this using a variety of measures, my approach is unique in the literature.

A second conclusion from introducing endogenous growth into a New Keynesian model is that monetary policy actions not only have short run but also long run consequences. This seems to counter the argument that in the long run money is neutral. However, long run output is still purely determined by supply factors, with the difference being that these are influenced by the short run monetary policy choice.

Third, when the zero bound on the nominal interest rate binds in face of a negative demand shock, then the impact of the endogenous growth rate on demand worsens the 
deflationary spiral that an economy hits. In such a case, the loss of power of monetary policy leads to large negative short and long run effects on output. However, such a situation also makes fiscal policy a lot more powerful, allowing large multipliers.

Finally, the combination of an endogenous growth model with a New Keynesian model allows to show that a savings shock by households does not necessarily have to lead to an increase in investment. In fact, the paradox of thrift can occur. The fall in demand decreases output so much, that investment falls despite a falling real interest rate. This is another novel finding in New Keynesian models.

This paper shows that the introduction of elements of endogenous growth into an otherwise standard New Keynesian model allows the analysis of persistent effects of temporary shocks. This persistence of effects introduces new channels through which policy can influence the economy. Specifically, it provides an opportunity for consumption crowding-in to exist that has not been found in the literature before.

\section{A Lower Zero Bound: Solution Strategy}

A usual solution procedure to solve a model with backward and forward looking variables is to obtain the $P-Q$ approach. These matrices allow the construction of the time series of the variables according to

$$
s_{t}=P s_{t-1}+Q \varepsilon_{t}
$$

The $P$ matrix shows the computed backward dynamics of each variable, while the $Q$ matrix shows the impact of shocks.

When non-linearities are present, the $P-Q$ approach does not work that simple, as these matrixes can only be calculated for a stable system. An interest rate fixed at zero leads to an unstable system (Woodford, 2003). However, Bodenstein et al. (2009) present a piecewise approach based on Eggertsson and Woodford (2003) to solve a model with a non-linear monetary policy rule as it is present here.

They solve the model using the $P$ - $Q$ approach, knowing that for periods $t \geq T+1$, where $T$ is the last period where the zero bound holds, the model can be solved using (23). All that remains to be done is to find transition matrices from period $t=0$ to period $t=T$ for $s_{t}$, knowing that $s_{0}=0$. These matrices are derived in Bodenstein et al. (2009), where I additionally allow for the shock term to have an autoregressive process. 
This adds (using the notation in Bodenstein et al. (2009))

$$
\begin{aligned}
F^{(1)} & =-\left(\bar{A} P+B^{*}\right)^{-1}\left(\bar{D}+Q \rho^{\varepsilon}\right) \\
F^{(T-t+1)} & =\left(I-A G^{(T-t)}\right)^{-1}\left(A F^{(T-t)} \rho^{\varepsilon}+D\right) \\
s_{1} & =h^{(T)}+F^{(T)} \varepsilon_{1} \\
s_{t} & =G^{(T-t+1)} s_{t-1}+h^{(T-t+1)}+F^{(T-t+1)} \rho^{\varepsilon} \varepsilon_{t}
\end{aligned}
$$

With this methodology the dynamic paths of the growing variables in terms of $T$ can be solved. This method, with appropriate adjustments, is also used to solve for the dynamic paths of variables when the interest rate is set discretely at $1 \%$ below its steady state level.

\section{References}

Altig, D., L. Christiano, M. Eichenbaum, and J. Lindé (2005). Firm-specific capital, nominal rigidities and the business cycle. NBER working paper (11034).

Barro, R. (1990). Government spending in a simple model of endogeneous growth. Journal of Political Economy 98(5), 103-125.

Baxter, M. and R. G. King (1993). Fiscal policy in general equilibrium. The American Economic Review 83(3), 315-334.

Blanchard, O. and R. Perotti (2002). An empirical characterization of the dynamic effects of changes in government spending and taxes on output. The Quarterly Journal of Economics 117(4), 1329-1368.

Blanchard, O. J. and D. Quah (1989). The dynamic effects of aggregate demand and syupply disturbances. The American Economic Review 79(4), 655-673.

Bodenstein, M., C. J. Erceg, and L. Guerrieri (2009). Effects of foreign schocks when interest rates are zero. International Finance Discussion Papers (983).

Calvo, G. A. (1983). Staggered prices in a utility-maximizing framework. Journal of Monetary Economics 12, 383-398.

Campbell, J. Y. and N. G. Mankiw (1987). Are output fluctuations transitory? The Quarterly Journal of Economics 102, 857-880.

Christiano, L., M. Eichenbaum, and S. Rebelo (2009). When is the government spending multiplier large? NBER Working Paper (15394). 
Cogan, J. F., T. Cwik, J. B. Taylor, and V. Wieland (2010). New Keynesian verus old Keynesian government spending multipliers. Journal of Economic Dynamics and Control 34(7236), 281-296.

Comin, D. and M. Gertler (2006). Medium-term business cycles. The American Economic Review 96(3), 523-551.

Diebold, F. X. and G. D. Rudebusch (1989). Long memory and peristence in aggregate output. Journal of Monetary Economics 24, 189-209.

Eggertsson, G. B. and M. Woodford (2003). The zero bound on interest rates and optimal monetary policy. Brookings Papers on Economic Activity 1, 139-233.

Galí, J., J. D. López-Salido, and J. Valles (2007). Understanding the effects of government spending on consumption. Journal of the European Economic Association 5(1), 227270.

Hall, R. E. (2009). By how much does GDP rise if the government buys more output? NBER Working Paper (15496).

Kühn, S. and J. Muysken (2009). Why inflation targeting central banks seem to follow a standard Taylor rule. Meteor Research Memorandum (RM/09/058).

Kühn, S., J. Muysken, and T. van Veen (2010). The adverse effects of government spending on private consumption in New Keynesian models. Metroeconomica, forthcoming.

Linnemann, L. and A. Schabert (2003). Can fiscal spending stimulate private consumption? Economic Letters 82, 173-179.

Murray, C. J. and C. R. Nelson (2002). The great depression and output persistence. Journal of Money, Credit and Banking 34, 1090-1098.

Nakov, A. (2008). Optimal and simple monetary policy rules with a zero floor on the nominal interest rate. International Journal of Central Banking 4, 73-127.

Nelson, C. R. and C. I. Plosser (1982). Trends and random walks in macroeconomic time series: some evidence and implications. Journal of Monetary Economics 10, 139-162.

Ramey, V. A. (2009). Identifying government spending shocks: It's all in the timing. NBER Working Paper (15464).

Rannenberg, A. (2009). Explaining european unemployment with a new keynesian new growth model. In E. Hein, T. Niechoj, and E. Stockhammer (Eds.), Macroeconomic Policies on Shaky Foundations - Whither Mainstream Economics? Metropolis. 
Reifschneider, D. and J. C. Williams (2000). Three lessons for monetary policy in a low-inflation era. Journal of Money, Credit and Banking 32, 936-966.

Romer, D. (2006). Advanced Macroeconomics, Chapter 3, pp. 100-170. McGraw-Hill.

Romer, P. (1986). Increasing returns and long-run growth. Journal of Political Economy 94(5), 1002-1037.

Romer, P. M. (1990). Endogenous technological change. Journal of Political Economy 98, S71-S102.

Romp, W. and J. de Haan (2007). Public capital and economic growth: A critical survey. Perspektiven der Wirtschaftspolitik 8, 6-52.

Schumpeter, J. (1939). Business cycles: a theoretical, historical, and statistical analysis of the capitalist process. McGraw Hill.

Smets, F. and R. Wouters (2003). An estimated dynamic stochastic general equilibrium model of the Euro area. Journal of the European Economic Association 1(5), 11231175 .

Smets, F. and R. Wouters (2007). Shocks and frictions in u.s. business cycles: A Bayesian DSGE approach. The American Economic Review 97(3), 506-606.

Stadler, G. W. (1990). Business cycle models with endogenous technology. The American Economic Review 80(4), 763-778.

Steindl, S. and G. Tichy (2009). Cycles and growth: an introduction. Empirica 36, $159-164$.

Turnovsky, S. J. (2000). Fiscal policy, elastic labour supply and endogenous growth. Journal of Monetary Economics 45, 185-210.

Woodford, M. (2003). Interest and Prices. Princeton University Press. 